\title{
INFLUENCE OF POLLUTION ON PHOTOSYNTHESIS PIGMENT CONTENT IN NEEDLES OF Picea abies AND Picea pungens IN CONDITIONS OF DEVELOPMENT OF IRON ORE DEPOSITS
}

\section{ELVIRA FEDORCHAK}

Kryvyi Rih Botanical Garden of the NAS of Ukraine, Marshak Str., 50, 50089, Kryvyi Rih, Ukraine; e-mail: huseinova93@gmail.com

\begin{abstract}
Fedorchak E.: Influence of pollution on photosynthesis pigment content in needles of Picea abies and Picea pungens in conditions of development of iron ore deposits. Ekológia (Bratislava), Vol. 39, No. 1, p. 1-15, 2020.

We studied photosynthetic pigments in needles of Picea abies and P. pungens in plantings exposed to aerotechnogenic influence of various levels in the big industrial center of steppe zone of Ukraine (Kryvyi Rih). We analyzed the pigment content in needles of the second year of life sampled from 30 to 40 -year-old trees of both species in 6 monitoring sites for 5 months. For the needles of $P$. abies and $P$. pungens from all the sites, we noticed the decreasing content of chlorophyll $a$ (to 27.2 and $25.0 \%$, respectively) and chlorophyll $b$ (to 17.9 and $20.0 \%$, respectively) from May till September, in comparison with background territory. At the same time, the content of carotenoids performing the protective function in photosynthetic reactions increased up to 26.1 and $24.0 \%$, respectively. For $P$. abies and $P$. pungens growing in conditions of intensive technogenic pressure, we ascertained that, during investigations, the sum of chlorophylls $(a+b)$ rate decreased to 24.4 and $23.6 \%$, respectively; ratio $(a / b)$ decreased to 11.4 and $12.3 \%$, respectively; ratio (chlorophylls $[a+b] /$ carotenoids) also decreased to 30.1 and $38.0 \%$, respectively, in comparison with plants from the least polluted site. It is shown that the most intensive negative influence on plantings is caused by industrial pollution and exhaust gases: the minimum or, more rarely, the maximum rates of pigment content appeared in needles of the plants exactly from these sites. Our research results demonstrate the feasibility of using the pigment complexes of $P$. abies and P. pungens, with the assimilative apparatus sensitive to air pollution damage, as indicators of air environmental conditions.
\end{abstract}

Key words: coniferous plants, assimilation apparatus, chlorophylls $a$ and $b$, carotenoids, aeropollutants.

\section{Introduction}

Ukraine stands out from other countries in Europe and throughout the world because of its large iron deposits (54\% of world reserves) (Kucherov, Ovchynnikova, 2009). During the extraction of iron ore, various types of pollutants are emitted into the atmosphere, the most common among them are dust, sulfur dioxide, carbon monoxide, hydrogen sulfide, nitrogen oxide, and others (Schwegler, 2006; Kucherov, Ovchynnikova, 2009). As a result of industrial 
activity, the state of environment in many industrial cities of the steppe zone of Ukraine is characterized as critical. Under such conditions, tree plantations play an important role in the system of measures for the improvement of the environment. Plants, being a reliable natural filter, clean, humidify, and enrich the air of cities with oxygen; reduce wind and noise; and change radiation and temperature (Nowak et al., 2014; Sergejchik, 2015; Bessonova, Ponomarova, 2017; Volodarets et al., 2018). However, they respond rapidly to the presence of even small doses of toxic substances in the air, being damaged by solid particles of industrial emissions that do not have visible effects on humans and animals. Therefore, plants are considered to be the best environmental indicators (Nowak et al., 2014; Uhrin, Supuka, 2016; Afanas'eva, 2018).

Of all the biodiversity of urban dendroflora, the species from the Pinaceae family are suggested for use as year-round bioindicators of aerotechnogenic contamination (Mosseler et al., 2001; Bessonova, Ponomarova, 2017; Korshikov et al., 2019), while deciduous trees, annually renewing leaves, clear up from toxic compounds (Doncheva, 1978). The assimilation apparatus in coniferous plants is a potentially reliable biomarker of the plant response to stress (Kvilala et al., 2014; Schiop et al., 2015). This point of view is proven by the studies conducted in the east of Ukraine, where representatives of the Pinaceae were introduced 30-40 years ago (Poljakov, Suslova, 2009).

Evaluation of the condition of urban plantations requires an early diagnosis of tree stand life, which allows obtaining shortly the complete information on the degree of technogenic impact on plantings. In the first place, the conifer damages manifest themselves at the physiological and biochemical levels (Starikova et al., 2016) and then extending to the ultrastructural and cellular level changes. And only afterwards, there develop visual signs of plant damage, namely, chloroses and necroses of needle tissues, needle fall, and decrease in needle length and growth of lateral shoots (Bacic et al., 2003; Pavlov 2005; Mikhailova et al., 2017). This susceptibility is explained by the fact that most important physiological processes are carried out in the assimilation apparatus, which is the center of variability or plasticity of the organism (Shubert, 1988). It is known that one of the biochemical indices of plant reaction to the change of environmental factors and adaptation degree to the new environmental conditions is the content of chlorophylls and carotenoids - the main photoreceptors of the photosynthetic cell (Di Vittorio, 2009; Verma, Chandra, 2014). The widely used indicators of needle damage caused by air pollution is the decrease in the chlorophyll content, as well as the difference in its $a$ and $b$ forms and carotenoid changes (Tausz et al., 1996; Lepedus et al., 2003; Bessonova et al., 2004). Many foreign and domestic authors discuss the physiology of the impact of harmful emissions from industrial enterprises (Lepedus et al., 2003; Mikhailova et al., 2017) and vehicle exhaust gases (Verma, Chandra, 2014; Bessonova, Ponomar'ova, 2017) on the pigment content in coniferous plants.

In Kryvyi Rih, with the annual industrial emissions of 358,600 tons in 2011 (Gryshko et al., 2012), such investigations should become an integral part of environmental monitoring. In this case, because of the absence of aboriginal coniferous plants, there is a need to use introduced species in the course of such investigations. Among the coniferous species commonly used in landscaping in Kryvyi Rih are Picea abies (L.) Karst and P. pungens Engelm., 
which grow in single, roadside, group and block plantings that facilitate using them as test systems for bioindication.

It should be noted that the earlier studies of the pigment complex of coniferous plants under conditions of high air pollution (in the Russian city of Izhevsk) characterized P. pungens as a more stable species compared to $P$. abies because of the increased content of chlorophyll $a$ (Bukharina et al., 2016). However, a number of researchers (Soukupova et al., 2001) observed that the needles of $P$. abies and $P$. pungens have the same degree of damages in response to atmospheric air pollution and the number of pigments in the latter species, on the contrary, is smaller. Therefore, it is relevant to compare the pigment complex and its contents in both spruce species during the growing season, which will allow us to evaluate the plant reaction to the effect of technogenic pollution.

The aim of our investigation is to find out the features of the seasonal dynamics of photosynthetic pigments content in the assimilation apparatus of the species $P$. abies and P. pungens in plantations exposed to different levels of aerotechnogenic influence in the conditions of a large industrial city in the steppe zone.

\section{Material and methods}

The research material was the needles of the second year of life sampled from 30 to 40 -year-old trees of $P$. abies and $P$. pungens during the growing season in 2017. The tree form with blue-green needles ( $P$. pungens "Glauca") was investigated as the most widely used in landscaping in Kryvyi Rih and other cities of Ukraine (Bilyk, Grabovyj, 2006).

It is theoretically grounded to use for such investigations the needles of certain age: on the one hand, fully developed and stable and, on the other hand, without any signs of aging (Zarek, 2016). The specific features of the initial development period of needles sampled for analysis were determined by the weather conditions of the growing season in 2017. The air temperature in relation to the long-term average monthly figures was normal: 15.5 (May) to $24.4^{\circ} \mathrm{C}$ (August). The maximum deviation of the temperature from the standard exceeded the multi-year indicators by $+3.2^{\circ} \mathrm{C}$ in August. The highest humidity (86\%) was registered in July and the lowest (42\%) in June (http://www. pogodaiklimat.ru). Dry periods alternated with rain. There were no climatic anomalies substantially changing the initial proportions of the individual component contents in the pigment complex.

The 6 main monitoring plantations are concentrated in two districts of the city: Metallurgical and Ternivsky (Fig. 1). Two of them are relatively weakly exposed to air pollution: the first was located in the Arboretum of the Kryvyi Rih Botanical Garden of the National Academy of Sciences of Ukraine, henceforward referred to as KBG (Section 1, control), and the second was located in Antiterrorist Operation Heroes' Park (Section 2). The next two are the roadside stands along Cherkasova Street (Section 3) and especially heavily trafficked Metallurgists' Avenue (Section 4), where the number of cars in 1 hour is 3 times greater than that in the Cherkasova Street. The highest concentrations of aerotechnogenic emissions are observed at Section 5 near the Private JSC 'North Ore Dressing Combine' (henceforward referred to as Northern GOK) and Section 6 near the metallurgical giant Public JSC "ArcelorMittal Kryviy Rih".

In each monitoring site, a total of 10 samples were collected from 7 trees of $P$. abies and P. pungens. In order to determine the content of pigments, an average sample was replicated for five times: $2 \mathrm{~mL}$ of dimethyl sulfoxide (DMSO) was added to $0.1 \mathrm{~g}$ of the fragmented plant material and incubated in water bath at a temperature of $67^{\circ} \mathrm{C}$ for 3 hours. In the resulting extract, measurements were made using a spectrophotometer SF-2000 at a wavelength of 665 and $649 \mu \mathrm{m}$ for chlorophylls $a$ and $b$, respectively, and $480 \mu \mathrm{m}$ for carotenoids. The pigment content follows the following expressions:

$$
\begin{aligned}
& \mathrm{C}_{a}=12.19 \times \mathrm{A} 665-3.45 \times \mathrm{A} 649 ; \\
& \mathrm{C}_{b}=21.99 \times \mathrm{A} 649-5.32 \times \mathrm{A} 665 ; \\
& \mathrm{S}_{\text {car }}=(1000 \times \mathrm{A} 480-2.14 \times \mathrm{Ca}-70.16 \times \mathrm{Cb}) / 220
\end{aligned}
$$

where $C$ is the concentration of pigments, $\mathrm{mg} / \mathrm{mL}$ (Wellburn, 1994).

Statistical analysis was performed using Microsoft Office Excel 2003. To compare two independent samples, we used Student's $t$-criterion $(\mathrm{p} \leq 0.05)$. 


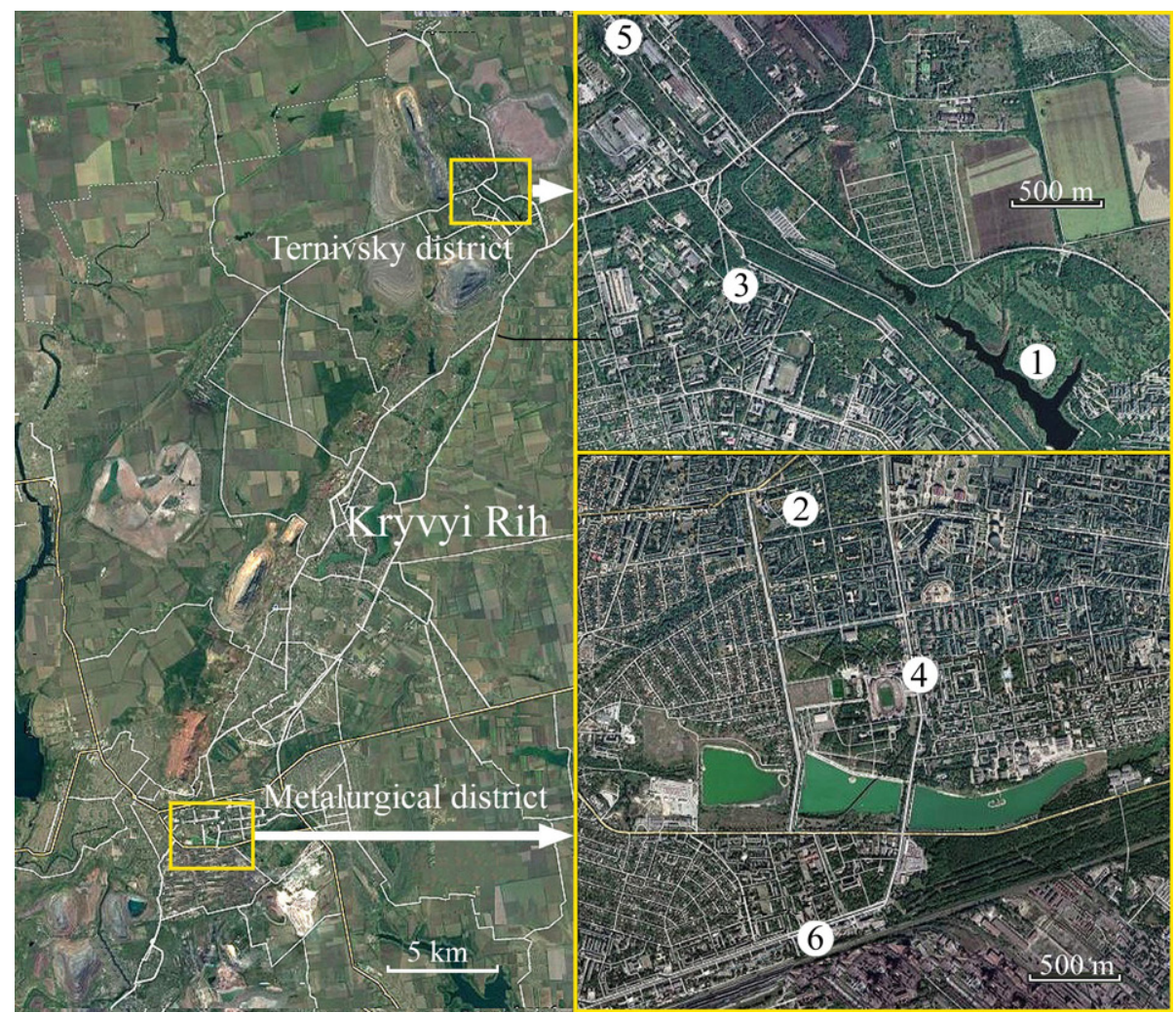

Fig. 1. Satellite data of the northern and central parts of Kryvyi Rih (available from https://www.google.com/

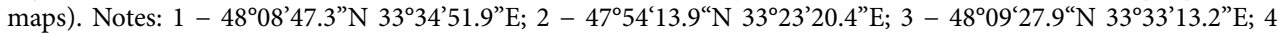

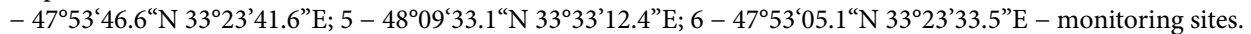

\section{Results}

For early manifestations of the plant stress condition induced by pollution at the physiological and biochemical levels, the contents of chlorophyll $a$ and $b$ content, which are sensitive to the activity of air pollutants, are most often used as indicators.

The maximum content of chlorophyll $a$ in the needles of $P$. abies and P. pungens was fixed in May (1.04 and $1.24 \mathrm{mg} / \mathrm{g}$ of wet weight, respectively) in a relatively "clean" area (control) (Fig. 2), which was higher, on an average, by 16.3 and $20.6 \%$, respectively, than that of plants from industrial sites. Somewhat smaller differences were observed in the trees of $P$. abies and $P$. pungens in roadside stands; the values were lower, on an average, by 14.4 and $14.9 \%$ compared with those in the KBG.

The lowest chlorophyll content in P. abies and P. pungens was recorded at ArcelorMittal Kryviy Rih site in September ( 0.58 and $0.70 \mathrm{mg} / \mathrm{g}$ wet weight, respectively), which is lower by 21.6 and $29.3 \%$, respectively, compared to plants from the Botanical Garden. For both 

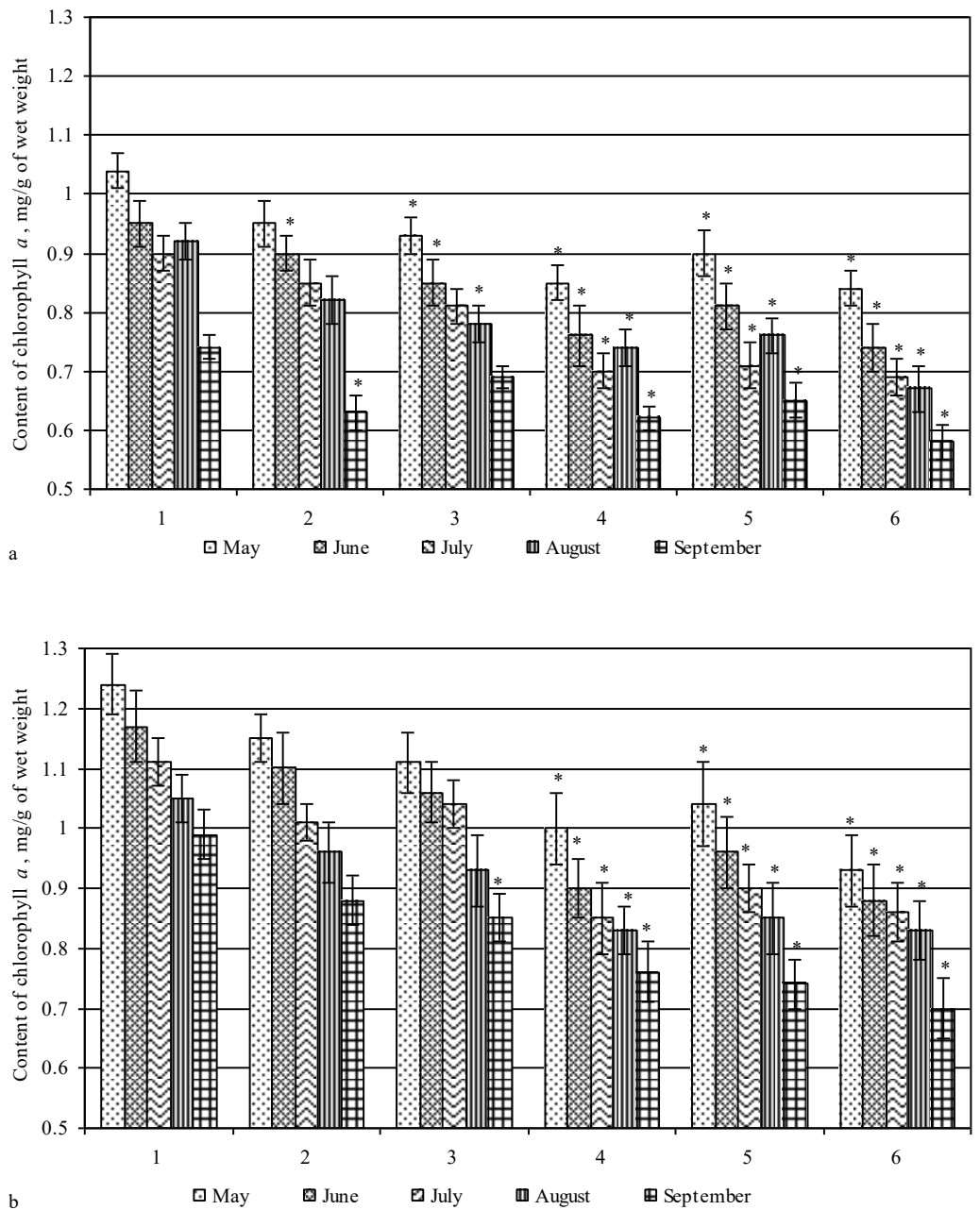

Fig. 2. Quantitative content of chlorophyll $\mathrm{a}, \mathrm{mg} / \mathrm{g}$ of wet weight, in the species of Picea abies (a) and Picea pungens (b) from different plantations of Kryvyi Rih (Sections 1-6; $n=5$; ${ }^{*}$ represents that the values are significantly different from the control at $\mathrm{p} \leq 0.05$ ).

species, we observed a general tendency to reduce this pigment during summer and autumn, especially in September, as this period was characterized by low rainfall and air drought. In the course of 5-month studies, a significant decline in the chlorophyll $a$ in both tree species in roadside stands and industrial sites was observed, especially in P. abies. In the needles of $P$. pungens in the urban plantations, the content of chlorophyll $a$ was relatively stability as well as its concentration was higher than that in P.abies, which is more sensitive to technogenic influence.

The maximum accumulation of chlorophyll $b$ in $P$. abies and $P$. pungens was observed in May in KBG ( 0.41 and $0.50 \mathrm{mg} / \mathrm{g}$ of wet weight, respectively), which is higher, on an average, 

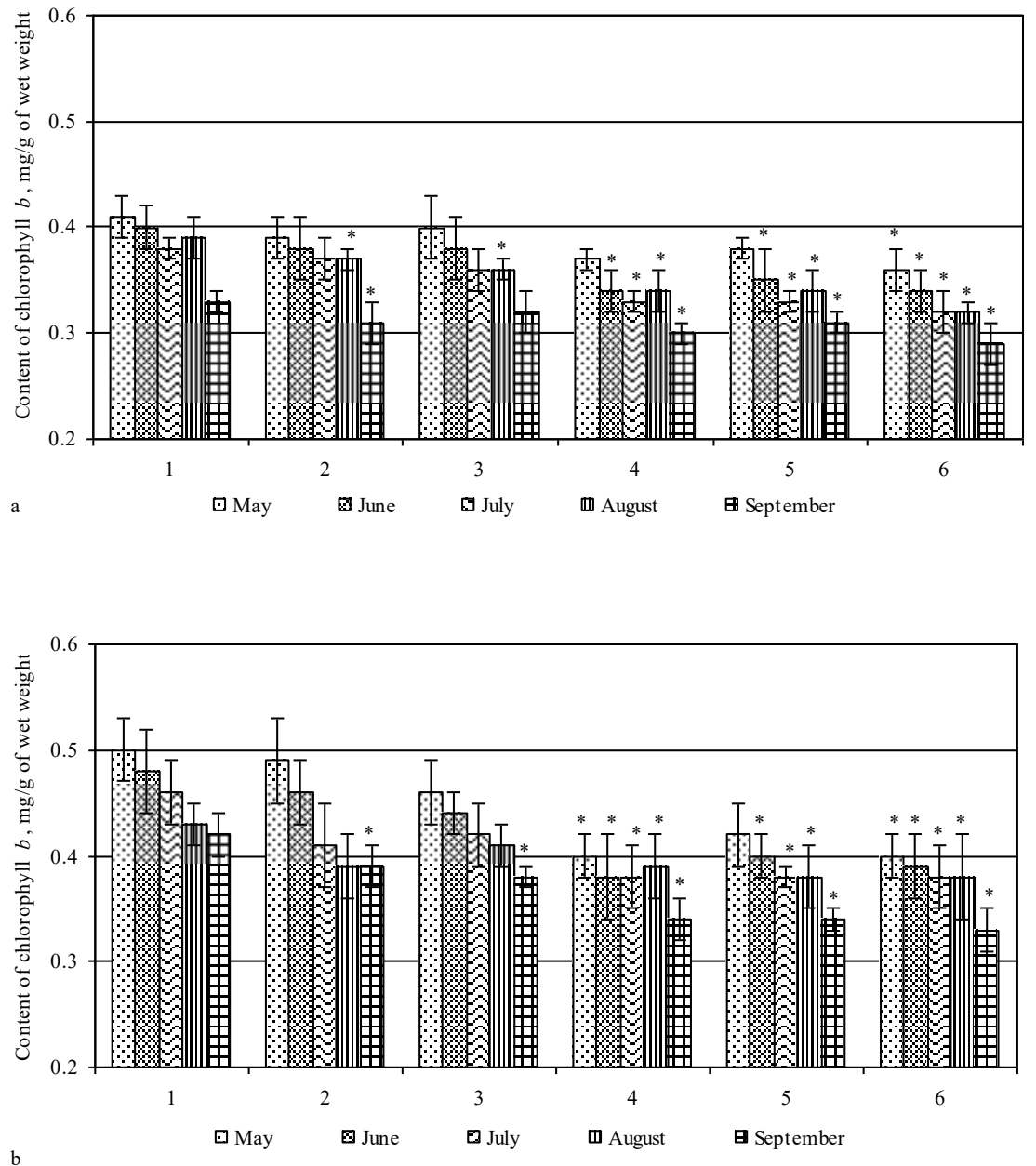

Fig. 3. Quantitative content of chlorophyll b, mg/g of wet weight, in the species of Picea abies (a) and Picea pungens (b) from different plantations of Kryvyi Rih (Sections 1-6; $n=5$; ${ }^{*}$ represents that the values are significantly different from the control at $\mathrm{p} \leq 0.05)$.

by 9.8 and $18.0 \%$, respectively, when compared to trees growing near industrial enterprises and by 6.1 and $14.0 \%$, respectively, when compared to those for roadside stands (Fig. 3).

The content of chlorophyll $b$ was found to be minimal in the needles of $P$. abies and $P$. pungens in September at the ArcelorMittal Kryviy Rih site $(0.29$ and $0.33 \mathrm{mg} / \mathrm{g}$ of wet weight, respectively), which is lesser by 14.7 and $21.4 \%$, respectively, less compared to the plants of the Botanical Garden. During the 5 months of investigations, there was an insignificant increase in the chlorophyll $b$ in the stands of both spruce species with the distance from roads and industrial emissions of ore mining and processing enterprises and also from metallurgical combines. 

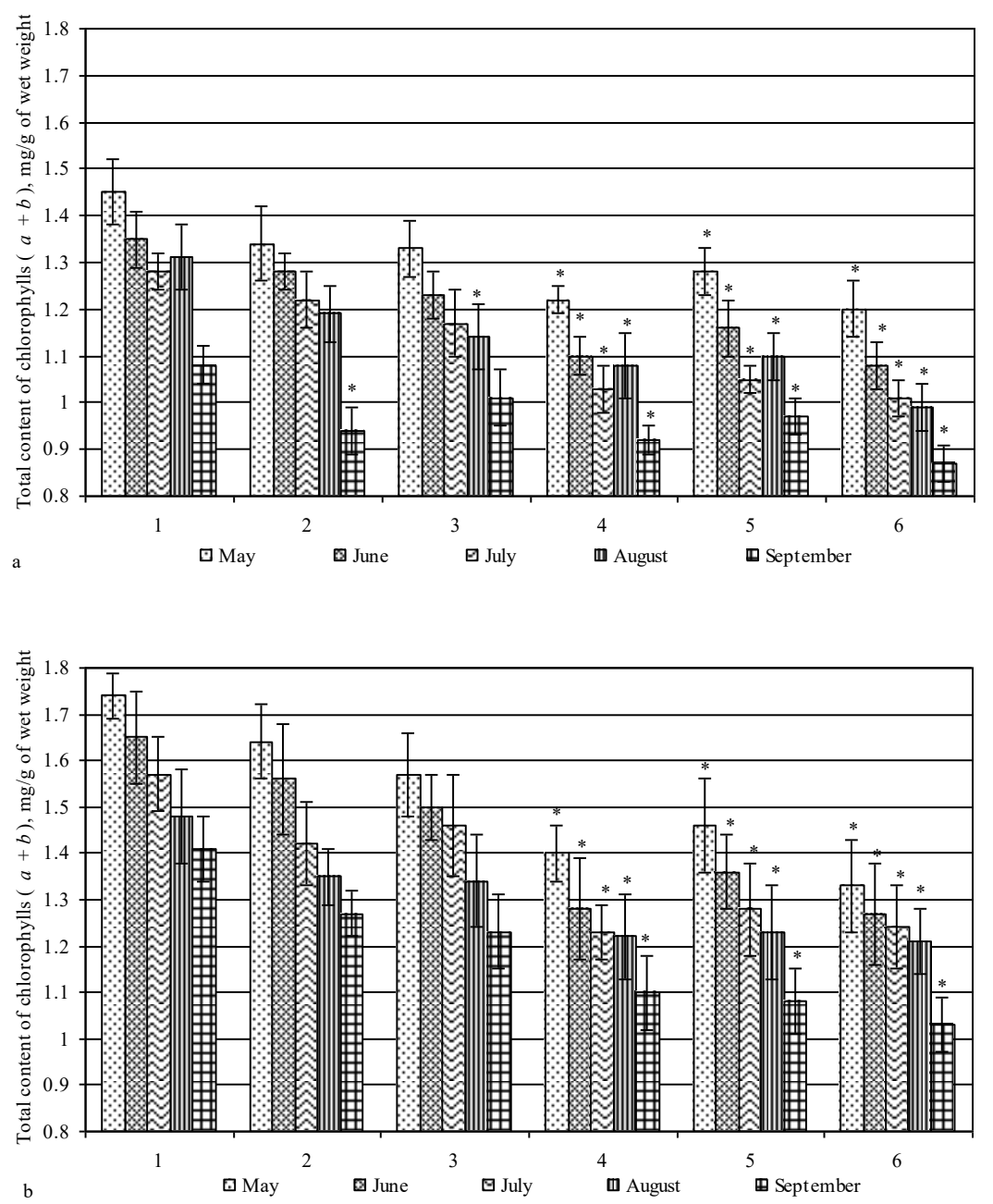

Fig. 4. Total content of chlorophylls $(a+b), \mathrm{mg} / \mathrm{g}$ of wet weight, in the species of Picea abies (a) and Picea pungens (b) from different plantations of Kryvyi Rih (Sections $1-6 ; n=5 ;{ }^{*}$ represents that the values are significantly different from the control at $\mathrm{p} \leq 0.05)$.

The highest values of the sum of chlorophylls $(a+b)$ in plants of the genus Picea were observed in May (Fig. 4). The maximum indices for all the six plantations were recorded in this period in the needles of $P$. abies $(1.45 \mathrm{mg} / \mathrm{g}$ of wet weight) and $P$. pungens $(1.74 \mathrm{mg} / \mathrm{g}$ of wet weight) in the KBG, which is higher, on an average, by 14.5 and $19.8 \%$ when compared to the trees from industrial sites. The largest number of chlorophylls in the needles of both species in May is due to the beginning of vegetation, sufficient rainfall, and not very hot weather compared with the following months. When comparing the sum of chlorophylls $(a+$ 

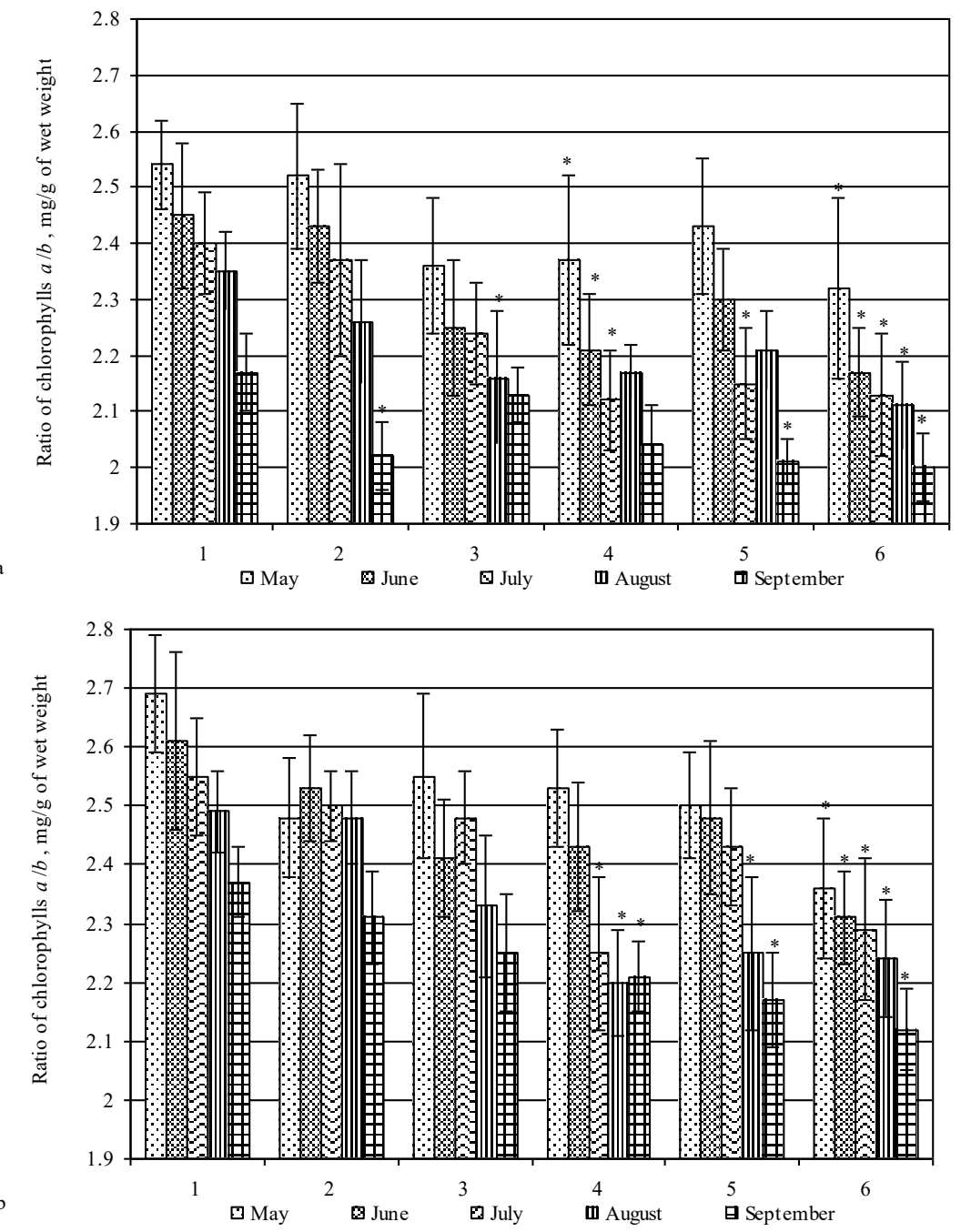

Fig. 5. Ratio of chlorophylls ( $a / b), \mathrm{mg} / \mathrm{g}$ of wet weight, in the species of Picea abies (a) and Picea pungens (b) from different plantations of Kryvyi Rih (Sections $1-6 ; n=5 ;{ }^{*}$ represents that the values are significantly different from the control at $\mathrm{p} \leq 0.05)$.

b) between these species in May in plantations of the KBG, it was observed that in P. pungens, this figure was greater by $16.7 \%$ when compared to $P$. abies. Within 5 months, a decrease in the sum of chlorophylls $(a+b)$ in plants of both species of the Picea genus was observed in all monitoring sites, but the values significantly differed from control in trees from industrial sites, less frequently along highways. 
It was revealed that the lowest values of the sum of chlorophylls for 5 months were characteristic of pigment complexes of both tree species in plantations from the metallurgical region (40 km south of the KBG of the National Academy of Sciences of Ukraine). In plants of $P$. abies and P. pungens near ArcelorMittal Kryvyi Rih, in the last month of the growing season, the sum of chlorophylls was 0.87 and $1.03 \mathrm{mg} / \mathrm{g}$ of wet weight, respectively, which was significantly lower by 19.4 and $27.0 \%$ compared to the trees of the Botanical Garden. In the plantations along the Metallurgists Avenue, the sum of pigments in the needles of both spruce species was lower by 8.9 and $10.7 \%$, respectively, compared with similar indicators of trees from roadside planting in Cherkasova Street. This trend was also observed in the ATO Heroes' Park, where the values were smaller compared with the trees of the Botanical Garden but not statistically reliable. Obviously, the transport exhaust gases and the emissions from ArcelorMittal Kryviy Rih metallurgical plant negatively affected the content of photosynthetic pigments. The impact of climatic factors such as air temperature and rainfall, which depend on the geographical location, is also significant. Less amount of atmospheric precipitation in the southern regions of the city causes a retarded development of the assimilation apparatus, reflected in the number of pigments.

The content of chlorophylls $(a / b)$ is one of the informative parameters that are characteristic of the photosynthetic apparatus function. Depending on the increase in the proportion of chlorophyll $a$ in this ratio, the process of photosynthesis is activated. The highest values of chlorophyll ratio $(a / b)$ in the needles of $P$. abies $(2.54 \mathrm{mg} / \mathrm{g}$ of wet weight) and $P$. pungens $(2.69 \mathrm{mg} / \mathrm{g}$ of wet weight) were found in the trees from the Botanical Garden in May and were higher, than in other investigated plantations, during the growing season (Fig. 5).

The smallest ratio of chlorophylls $(a / b)$ was observed in the needles of $P$. abies and P. pungens in September (2.0 and $2.12 \mathrm{mg} / \mathrm{g}$ of wet weight, respectively) near ArcelorMittal Kryviy Rih, which is less by 7.8 and $10.5 \%$, respectively, compared to the trees from the KBG. The similar data for both species were observed during 5 months near the Metallurgists Avenue; that can be explained by the excessive impact of exhaust gases and the industrial emissions in the Metallurgical District.

Carotenoids are compulsory components of the plant pigment system. Their number in the needles of both species from the genus Picea for 5 months changed from 0.20 to 0.34 $\mathrm{mg} / \mathrm{g}$ of wet weight; the concentration increased in line with the increase in the pollution level (Fig. 6). Thus, their highest content of 0.32 and $0.34 \mathrm{mg} / \mathrm{g}$ of wet weight was detected in the needles of $P$. abies and P. pungens, respectively, in September at ArcelorMittal Kryviy Rih site, which is more by 18.5 and $21.4 \%$, respectively, compared to the trees from KBG. Values close to these were observed in the trees of both species from the site near PJSC "NorthernGOK" and along highways, indicating their protective reaction to atmospheric air pollutants.

The smallest amount of carotenoids in the needles of $P$. abies and $P$. pungens was recorded in all monitoring plots in May, especially in the trees from KBG $(0.20$ and $0.22 \mathrm{mg} / \mathrm{g}$ of wet weight, respectively). For 5 months, there were no significant differences in the carotenoid content in the species of the genus Picea from different investigated sites.

The ratio of the sum of chlorophylls to the concentration of carotenoids plays an important role in the work of the photosynthetic apparatus. This indicator reflects the reaction of sensitivity in coniferous plants to various changes in the environment. The minimum values 

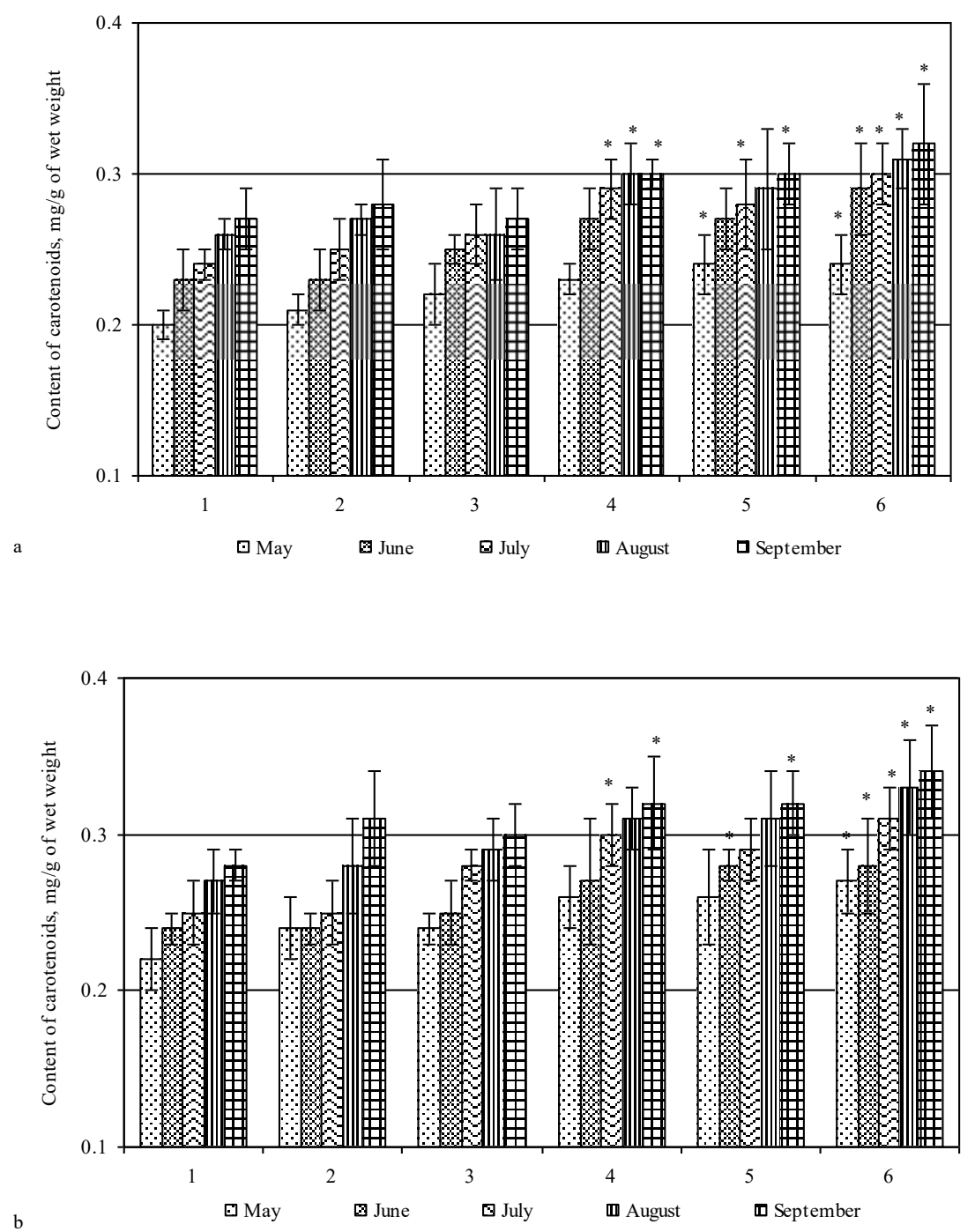

Fig. 6. Quantitative content of carotenoids, $\mathrm{mg} / \mathrm{g}$ of wet weight, in the species of Picea abies (a) and Picea pungens (b) from different plantations of Kryvyi Rih (Sections 1-6; $n=5$; ${ }^{*}$ represents that the values are significantly different from the control at $\mathrm{p} \leq 0.05)$.

( 2.74 and $3.04 \mathrm{mg} / \mathrm{g}$ of wet weight, respectively) in the needles of P. abies and P. pungens trees were recorded in September at ArcelorMittal Kryviy Rih site, which is less by 30.6 and $40.3 \%$, respectively, compared to the trees from the Botanical Garden (Fig. 7). 

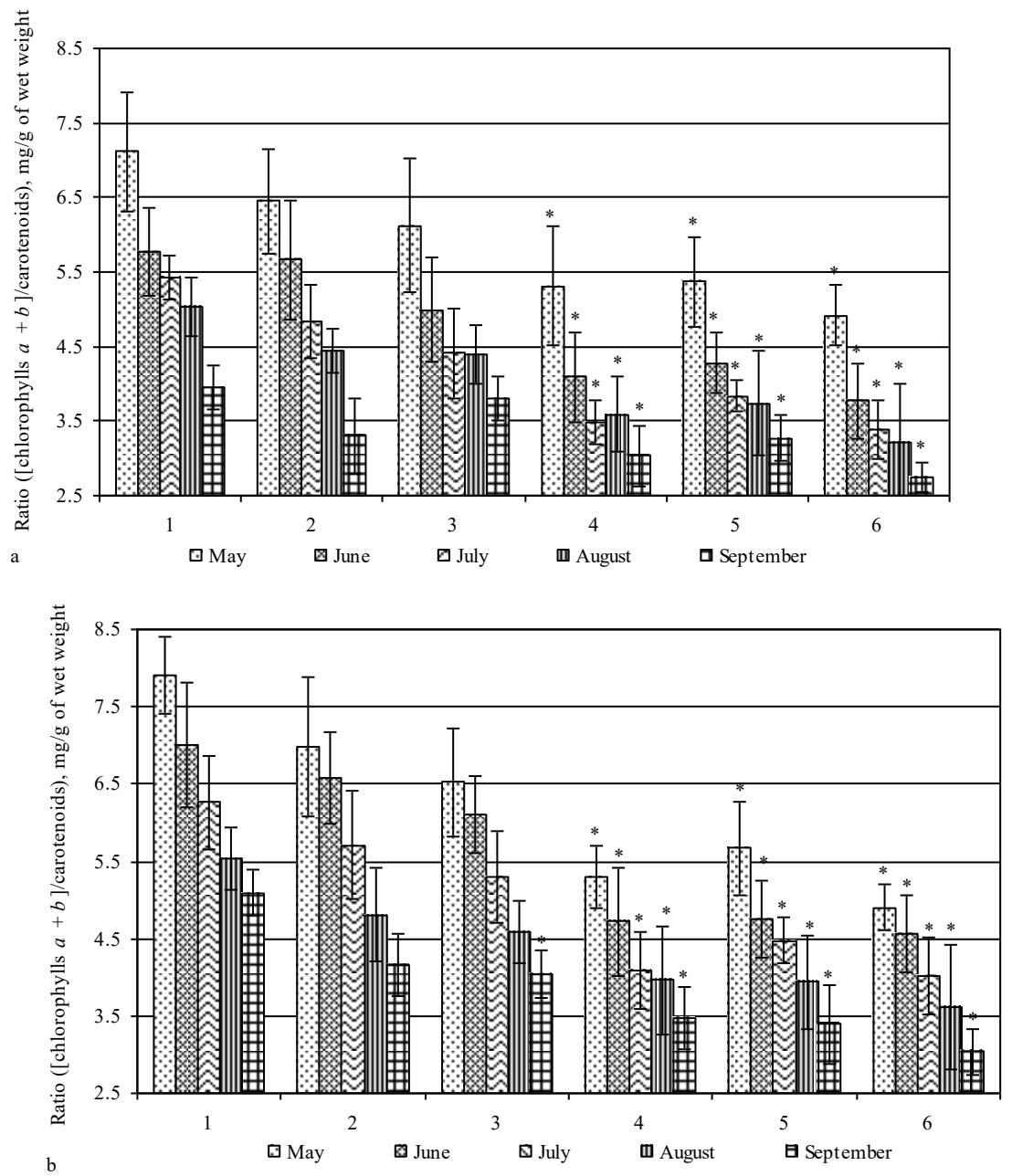

Fig. 7. Ratio ([chlorophylls $a+b] /$ carotenoids), $\mathrm{mg} / \mathrm{g}$ of wet weight, in the species of Picea abies (a) and Picea pungens (b) from different plantations of Kryvyi Rih (Sections 1-6; $\mathrm{n}=5$; ${ }^{*}$ represents that the values are significantly different from the control at $\mathrm{p} \leq 0.05)$.

The reduced value of this ratio indicates deterioration of the photosynthetic activity in trees under conditions of atmospheric air pollution. The greater is the distance between Picea plantations and the sources of industrial emissions, the higher is the ratio ([chlorophylls $a$ $+b]$ /carotenoids) in spruce needles. The maximum value of the ratio ([chlorophylls $a+b] /$ carotenoids) was detected in May (7.12 and $7.90 \mathrm{mg} / \mathrm{g}$ of wet weight, respectively) in the needles of $P$. abies and $P$. pungens trees growing in the KBG. These values are higher, on an 
average, by 27.7 and $33.1 \%$, respectively, compared to those in the trees from industrial sites and by 19.7 and $25.2 \%$, respectively, compared to those for roadside trees.

The range of the pigment content in the photosynthetic apparatus of conifers over the year depends on the climatic conditions and environmental factors of the urban technogenic environment as well as on the geographical position. The reduction of pigment rates was observed in the Metallurgical District, located in the southern part of the city where, to make it worse, the metallurgical plant-the "record holder" among air pollution sources-is situated.

Our research on the effects of atmospheric pollution by car exhaust gases and toxic industrial emissions on the chlorophyll pigment complex of coniferous plants in the Kryvyi Rih plantations has shown that the increase in the concentration of air pollutant significantly changes the number and proportions of individual components of pigment complex. The rapid plant response to stress, which occurs at the physiological and biochemical levels, further affects the vital state and plant ornamental features.

\section{Discussion}

The amount of chlorophylls $a$ and $b$ is of particular importance among the informative diagnostic indicators of the state of photosynthetic apparatus and the adaptive capacity of plants (Verma, Chandra, 2014). The largest amount of chlorophyll $a$ in the needles of $P$. abies and P. pungens was observed in May by other researchers (Lepedus et al., 2003; Titova, 2013; Bessonova, Ponomarova, 2017). This is due to the sufficient rainfall in the start of vegetation, and optimal air temperature for the plant development, increasing during the next months. The minimum amount of chlorophyll $a$ in the species from the genus Picea, as well as in another representative of the conifers, namely, Pinus nigra subsp. pallasiana (Lamb.), was registered during the second half of the summer and autumn (Deligöz et al., 2018). It is noted that during prolonged droughts, the destruction of chlorophyll $a$ is greater than $b$ (Pavlov, 2005).

Investigations on the pigment complex of coniferous plants in Izhevsk have proved that Picea pungens is characterized as a species more resistant to air pollution than $P$. abies, as the reaction of the first species pigment complex to adverse environmental conditions is detected only in conditions of high air pollution (Bukharina et al., 2016). The highest content of chlorophyll $a$ (0.9-1.2 mg/g of wet weight) was observed in introduced plantations of $P$. pungens in control territories, and the lowest $(0.6-0.9 \mathrm{mg} / \mathrm{g}$ of wet weight) was observed in those in roadsides (Bessonova, Ponomar'ova, 2017). Close to our results, the values of chlorophyll content $b$ in the needles of $P$. abies $(0.37 \mathrm{mg} / \mathrm{g}$ of wet weight) and $P$. pungens $(0.51 \mathrm{mg} / \mathrm{g}$ of wet weight) were measured by Titova $(2010,2013)$ in trees from the Arboretum of the Ussuriisk region of Russia. In this regard, the results of our investigations agree with those published by other researchers.

It is known from earlier publications that pollutants weaken the accumulation of chlorophyll $b$ more than chlorophyll $a$, which may reduce the activity of the photosynthetic apparatus and disrupt the metabolism of plants (Tuzhilkina et al., 1988; Lepedus et al., 2003). However, other researchers (Sergejchik, 2015; Bukharina et al., 2016), on the contrary, emphasize the predominance of quantitative changes in the content of chlorophyll $a$ in the pigment complex of conifers in urban areas; the content of chlorophyll $b$ remains relatively stable. In 
our case, the second variant of the dynamic changes of the pigment complex is confirmed: the increase in the level of pollution of the urban environment more significantly decreases the amount of chlorophyll $a$ than $b$.

In a number of articles (Miron, Sumalan, 2015; Mikhailova et al., 2017; Afanaseva, 2018; Bessonova, Grytsay, 2018), it has been shown that chlorophyll reacts sensitively to all changes in the metabolism and, in adverse conditions, changes in its total content $(a+b)$ and the ratio of individual forms $(a / b)$. As for such an indicator the amount of chlorophylls $(a+b)$ we should note that the results of author's research in general are the same as others: in the needles of P. abies from Ussuriisk, it was $1.11-1.38 \mathrm{mg} / \mathrm{g}$ of wet weight (Titova, 2010), and in the needles of $P$. pungens from the city of Dnipro (Ukraine), it was $0.99-1.7 \mathrm{mg} / \mathrm{g}$ of wet weight (Bessonova, Ponomarova, 2017). The peculiarities of pigment accumulation in conifers during the vegetation period are also confirmed by other studies: the most intensively this process takes place in May (Titova, 2013; Bessonova, Ponomarova, 2017), the smallest number is observed in September (Zarek, 2016; Deligöz et al., 2018). Our data also proved the previously statements (Kvilala et al., 2014; Verma, Chandra, 2014; Starikova et al., 2016 Bessonova, Grytsay, 2018) on the overall decrease in the number of chlorophylls in plant photosynthetic apparatus under stress.

The data revealing the degree of stability of the photosynthetic apparatus of various coniferous plants to the effects of adverse factors still remain controversial. Some authors (Soukupova et al., 2001) stated that two species of spruce (P. abies and P. pungens) exhibit the same inhibition effects on functioning of the pigment complex under the influence of toxicants, whereas we have reasons to indicate a better adaptive balance of pigment content in $P$. pungens.

It was found that increased concentrations of air pollutants lead to a decrease in the ratio of chlorophylls and to an increase in the concentration of carotenoids (Bessonova, Ponomarova, 2017). In particular, an increase in the concentration of carotenoids in the needles of $P$. pungens in response to air pollution was detected in various macroclimatic conditions (Bukharina et al., 2016; Starikova et al., 2016; Bessonova, Ponomarova, 2017). Thus, the content of carotenoids in the needles of the introduced plantings of $P$. abies from the Arboretum of the Ussuriisk, where the air can be considered relatively "pure", amounted to $0.19-0.22 \mathrm{mg} / \mathrm{g}$ of wet weight (Titova, 2010). For the needles of the same tree species from the plantations of Osijek under conditions of atmospheric pollution with cement dust, this indicator was $0.21-0.25 \mathrm{mg} / \mathrm{g}$ of wet weight (Lepedus et al., 2003). Significantly larger quantities of this indicator $(0.20-0.37 \mathrm{mg} / \mathrm{g}$ of wet weight) were observed in the needles of P. pungens from roadsides of the city of Dnipro (Bessonova, Ponomarova, 2017). Such data in general agree with our data, obtained during investigations in Kryvyi Rih Region. We believe that in our case, the increase in the concentration of carotenoids within pigment complexes of trees growing close to industrial enterprises and highways in comparison to those from low-contaminated areas show protective response to man-induced impacts.

\section{Conclusion}

The results of our study show that the industrial emissions and vehicle exhaust gases of air pollutants in Kryvyi Rih significantly affect the pigment complex in the needles of P. abies 
and $P$. pungens. The decrease in the content of chlorophylls $a$ and $b$ in the needles of both investigated species of the genus Picea was observed for 5 months in comparison with the control "clean" territory. In this case, the amount of chlorophyll $a$ is reduced to a greater extent than chlorophyll $b$. It was found that the sum of the content of chlorophylls $(a+b)$ and their ratio in the needles of $P$. abies and $P$. pungens during the growing season increased in the plantings remote from industrial enterprises and highways, reaching the maximum figures of the indicators in May and the minimum indices in September, which is due to a decrease in the intensity of the photosynthetic apparatus activity and an unfavorable decrease in the air temperature. The study has shown that with the increase in pollution rates, the content of carotenoids was increased, which is associated with their protective function, whereas the ratio of the sum of chlorophylls $a$ and $b$ to the number of carotenoids in the needles of both species, on the contrary, decreased. It was found that in P. abies, the content of all pigments has values smaller than $P$. pungens, which indicates higher stability assimilation apparatus of the latter. In connection with the above, we suggest possible implications of the pigment complexes of $P$. abies and $P$. pungens as year-round available bioindicators of the air pollution state.

\section{References}

Afanas'eva, L.V. (2018). Physiological and biochemical adaptation of siberian larch Larix sibirica Ledeb. to the conditions of the urban environment (in Russian). Siberian Journal of Forest Science, 3, 21-29. DOI: 10.15372/SJFS20180303.

Bacic, T., Uzarevic, Z., Grgic, L., Rosa, J. \& Popovic Z. (2003). Chlorophylls and carotenoids in needles of damaged fir (Abies alba Mill.) from risnjak national park in Croatia. Acta Biol. Cracov., Ser. Bot., 45(2), 87-92.

Bessonova, V. \& Grytsay Z. (2018). Content of plastid pigments in the needles of Pinus pallasiana D. Don in different forest growth conditions of anti-erosion planting. Ekológia (Bratislava), 37(4), 338-344. DOI: 10.2478/eko-2018-0025.

Bessonova, V.P. \& Ponomar'ova O.A. (2017). Morphometric characteristics and the content of plastid pigments of the needles of Picea pungens depending on the distance from the highways (in Russian). Biosystems Diversity, 25(2), 96-101. DOI: 10.15421/01171.

Bessonova, V.P., Kapelyush, N.V., Ovcharenko, S.V. \& Pismenchuk V.D. (2004). Influence of multicompo-nent emissions of road transport on the content of chlorophyll in leaves of woody plants (in Russian). Bulletin of the Nikita Botanical Garden, 89, 73-75.

Bilyk, O.V. \& Grabovyj V.M. (2006). Spruce (Picea pungens Engelm.) in plantations of the National Dendroparks "Sofiyivka" of the National Academy of Sciences of Ukraine (introduction, reproduction, cultivation) (in Ukrainian). Scientific Bulletin of National Forestry University of Ukraine, 16(1), 44-48.

Bukharina, I.L., Vedernikova, K.E. \& Pashkova A.S. (2016). Morphophysiologic traits of spruce trees in conditions of Izhevsk. Forest Studies, 2, 96-106. DOI: 10.1134/S1995425516070027.

Deligöz, A., Bayar, E., Genç, M., Karatepe, Y., Kirdar, E. \& Cankara F. (2018). Seasonal and needle age-related variations in the biochemical characteristics of Pinus nigra subsp. pallasiana (Lamb.) Holmboe. J. For. Sci., 64(9), 379-386. DOI: 10.17221/66/2018-JFS.

Di Vittorio, A.V. (2009). Pigment-based identification of ozone-damaged pine needles as a basis for spectral segregation of needle conditions. J. Environ. Qual., 38(3), 855-867. DOI: 10.2134/jeq2008.0260.

Doncheva, A.V. (1978). Landscape in the impact zone of industry (in Russian). Moscow: Forest Industry.

Gryshko, V.M., Syshhykov, D.V., Piskovata, O.M., Danyl'chuk, O.V. \& Mashtaler N.V. (2012). Heavy metals: entering to soils, translocation in plants and ecological danger (in Ukrainian). Donetsk: Donbas.

Korshikov, I., Belonozhko, Y. \& Lapteva H. (2019). Cytogenetic abnormalities in seed progenies of Pinus pallasiana D. Don stands from technogenic polluted lands in the steppe of Ukraine. Ekológia (Bratislava), 38(1), 117-125. DOI: 10.2478/eko-2019-0009.

Kucherov, K.I. \& Ovchynnikova N.B. (2009). Current environmental security problems of mining-and-processing integrated works on the environment (in Ukrainian). Bulletin of V.N. Karazin Kharkiv National University, 849, 90-96. 
Kvilala, M., Lackova, E. \& Urbancova L. (2014). Photosynthetic active pigments changes in Norway spruce (Picea abies) under the different acclimation irradiation and elevated $\mathrm{CO}_{2}$. Environmental Chemistry, 1, 1-4. DOI: $10.1155 / 2014 / 572576$.

Lepedus, H., Cesar, V. \& Suver M. (2003). The annual changes of chloroplast pigments content in current- and previous-year needles of Norway spruce (Picea abies L. Karst.) exposed to cement dust pollution. Acta Botanica Croatica, 62(1), 27-35.

Mikhailova, T.A., Afanasieva, L.V., Kalugina, O.V., Shergina, O.V. \& Taranenko E.N. (2017). Changes in nutrition and pigment complex in pine (Pinus sylvestris L.) needles under technogenic pollution in Irkutsk region, Russia. J. For. Res., 22, 386-392. DOI: 10.1080/13416979.2017.1386020.

Miron, M.S. \& Sumalan R.L. (2015). Physiological responses of Norway spruce (Picea abies [L.] Karst) seedlings to drought and overheating stress condition. Journal of Horticulture, Forestry and Biotechnology, 19(2), 146-151. www.journal-hfb.usab-tm.ro

Mosseler, A., Major, J.E., Simpson, J.D., Daigle, B., Lange, K., Park, Y.S., Johnsen, K.H. \& Rajora O.P. (2001). Indicators of population viability in red spruce, Picea rubens. I. Reproductive traits and fecundity. Can. J. Bot., 78(7), 928-940. DOI: 10.1139/b00-065.

Nowak, D.J., Hirabayashi, S., Bodine, A. \& Greenfield E. (2014). Tree and forest effects on air quality and human health in the United States. Environ. Pollut., 193, 119-129. DOI: 10.1016/j.envpol.2014.05.028.

Pavlov, I.N. (2005). Woody plants in conditions of technogenic pollution (in Russian). Ulan-Ude: Science.

Poljakov, A.K. \& Suslova E.P. (2009). Results of the introduction of species of the genus Pinus L. in the south-east of Ukraine (in Russian). Industrial of Botany, 9, 101-104.

Schiop, S.T., Hassan, M.A., Sestras, A.F., Boscaiu, M., Sestras, R.E. \& Vicente O. (2015). Identification of salt stress biomarkers in Romanian carpathian populations of Picea abies (L.) Karst. PLOS ONE, 10(8), 14-22. DOI: 10.1371/journal.pone.0135419.

Schwegler, F. (2006). Air quality management: a mining perspective. Ecology and the Environment, 86, $205-212$. DOI: 10.2495/AIR06021.

Sergejchik, S.A. (2015). Ecological and physiological monitoring of the resistance of Scots pine (Pinus sylvestris L.) in the technogenic environment (in Russian). Biosphere, 7(4), 384-391.

Shubert, R. (1988). Bioindication of pollutants of terrestrial ecosystems (in Russian). Moscow: World.

Soukupova, J., Rock, B.N. \& Albrechtova J. (2001). Comparative study of two spruce species in a polluted mountainous region. New Phytol., 150(1), 133-145. DOI: 10.1046/j.1469-8137.2001.00066.x.

Starikova, E.A., Voskresenskaja, O.L. \& Sarbaeva E.V. (2016). Changes in the pigment complex of Picea pungens Engelm. in the urban environment (in Russian). International Journal of Research, 10(52), 45-48. DOI: 10.18454/IRJ.2016.52.044.

Tausz, M., De Kok, L., Stulen, I. \& Grill D. (1996). Physiological responses of Norway spruce trees to elevated $\mathrm{CO}_{2}$ and $\mathrm{SO}_{2}$ J. Plant Physiol., 362-367. DOI: 10.1016/S0176-1617(96)80266-5.

Titova, M.S. (2010). The content of photosynthetic pigments in the needles of Picea abies and Picea koraiensis (in Russian). Bulletin of the Orenburg State University, 118(12), 9-12.

Titova, M.S. (2013). Features of the photosynthetic activity of the needles of introduced species of Picea A. Dietr. in the arboretum of the mountain-taiga station (in Russian). Fundamental Research, 11, 128-132.

Titova, M.S. (2014). Comparative analysis of the accumulation of carotenoids in the needles (in Russian). Pacific Medical Journal, 2, 48-50.

Tuzhilkina, V.V., Ladanova, N.V. \& Pljusnina S.N. (1998). Influence of anthropogenic pollution on the photosynthetic apparatus of pine (in Russian). Ecology, 2, 89-93.

Uhrin, P. \& Supuka, J. (2016). Quality assessment of urban trees using growth visual and chlorophyll fluorescence indicators. Ekológia (Bratislava), 35(2), 160-172. DOI: 10.1515/eko-2016-0013.

Verma, V. \& Chandra N. (2014). Biochemical and ultrastructural changes in Sida cordifolia L. and Catharanthus roseus L. to auto pollution. International Scholarly Research Notices, 2014, 1-11. DOI: 10.1155/2014/263092.

Volodarets, S., Glukhov, A. \& Zaitseva I. (2018). Phytoncide activity of woody plants under the conditions of steppe zone. Ekológia (Bratislava), 37(3), 219-229. DOI: 10.2478/eko-2018-0018.

Wellburn, A.R. (1994). The spectral determination of chlorophyll $a$ and $b$, as well as total carotenoids, using various solvents with spectrofotometers of different resolution. J. Plant Physiol., 144, 307-313. DOI: 10.1016/S0176$1617(11) 81192-2$.

Zarek, M. (2016). Seasonal fluctuations of photosynthetic pigments content in Taxus baccata needles. Dendrobiology, 76, 13-24. DOI: 10.12657/denbio.076.002. 